Katarzyna Barańska

Jagiellonian University

Faculty of Management and Social Communication

Institute of Culture

\title{
„For the return of museum slippers”, i.e. an indication of selected possibilities for museums to respond to trends in changes in the natural and cultural environment
}

The underlying assumption of this essay was that museums are first and foremost leaning towards the FUTURE [cf. Barańska 2013: 93 et seq.] with the need to break out of the vicious circle of the underlying message that museums should only be perceived as dealing with the PAST. The things that are happening now, that are important for the world and for people, this „NOW” should be treated as a kind of challenge for museum work. While following the order of duty, we ought to point out that it is the present which is imperative for the work of museum professionals, when looking for exhibits to expand collections, arrange exhibitions or undertake educational activities. The imperative of monitoring trends, thoughts and problems that affect people - those of a social as well as an individual dimension - therefore seems to be a prerequisite for museum professionals as well as an essential area of their creative and professional contemplations and activity. By being alert and sensitive to human issues, and therefore alert and sensitive to problems relevant to people, museums will be able to participate in social and cultural dialogue, and will truly become es- 
tablishments that are meaningfully contributing to shaping reality. Only in this manner will they be able to deliver their duty of service as defined by ICOM [https://icom.museum/en/resources/standards-guidelines/museumdefinition, read: 1.09.2021] and by which they essentially maintain and will in the FUTURE maintain their raison d'être and justify the need for them to operate and be funded by public resources, both in economic and symbolic terms. Keeping a finger on the pulse of social issues becomes, in this sense, the main goal of institutions that are, after all, of great service to culture.

The subject of climate change, which is and the ways in which people can and must respond to what is happening to an environment can no longer be defined as ,natural' is now ubiquitous in the media and very much contemporary. The Anthropocene has become an irreversible fact [Żabicki, read 10.08.2021], so it is probably best to expand the mindset and speak of a "natural-cultural" environment. The extent of human interference with the way the climate, geological or natural environment is changing in all its dimensions cannot be overestimated and has long been beyond the point of sustainability. This balance, however, can and should be pursued, so "sustainable development" is a necessary and indispensable postulate. The implementation of this cannot be a decision of the future, but is a necessity of the present and of the NOW mentioned at the beginning of this article. Museum professionals, who after all are only a handful of people on Earth, should therefore treat the need to deal with the climate as a challenge not only for theoretical reflection, but also for day-to-day practice.

More and more is being written about how cultural institutions, including museums, can impact the reversing of climate change trends. Joanna Tabaka's studies, also featured in other contributions to the current issue of ZWAM, are particularly worthy of consideration in the Polish literature. In the last year, 2020, the author has published two monographs available for download in pdf file at [https://www.joannatabaka.pl/publikacje, read 17.08.2021]. In the paper: "The green institution of culture. On becoming a culture-friendly place of culture", the author points out a number of options for saving consumable raw materials, products and energy involved in production and various other endeavours. She does not address museums in any particular way here, but they do emerge as an exemplification of some of the suggestions.

The paper "Culture for nature, with the Mermaid of Warsaw in the background. Good Ecological Practices in Warsaw’s Cultural Institutions” explores 
the issue of designing such ways of operating cultural institutions that will ensure they strive to minimise the effects of pollution on the environment and show the directions that can be followed by institutions willing to act environmentally friendly and inspire others to do so. Tabaka discusses various Warsaw institutions, including both community centres and theatres, and addresses two museums: the POLIN Museum of the History of Polish Jews and the King John III Wilanów Palace Museum. The practices presented there aim to reduce the use of paper (through electronic document dissemination, the use of recycled paper for printing, abandoning printed materials for promotional purposes), water (through the use of tap water for drinking), energy (through energy-efficient lighting, refraining from overheating rooms), as well as the sorting and recycling of rubbish and display design. The Museum in Wilanów, having the „Morysin” nature reserve and park under its care, also engages in activities directly related to the environment, creating space for education and recreation [https://www.wilanow-palac.pl/ co_mozna_zobaczyc_w_parku.html, read:17.08.2021], and actively contributes to discussions on local development and land-use planning.

In view of the alarming state of the climate as described in the most recent report by the Intergovernmental Panel on Climate Change (IPCC), which came out in August of this year, all these measures are absolutely essential and imperative [https://www.teraz-srodowisko.pl/aktualnosci/ raport-IPCC-2021-zmiany-klimatu-10704.html, read: 16.08.21]. It is certainly important to take even the most minor action in this regard, but media reports and expert commentary suggest that the most important steps to halt environmental deterioration remain with governments and policymakers on the issue of gas emissions. Responsibility for recycling drinking water bottles or other plastic packaging is left to the individual user, but this is rather like bringing a knife to a gunfight. Nonetheless, a massive campaign of small actions can be instrumental in delaying the incoming threat, raising environmental awareness and thus supporting those political decisions that can have a positive impact on the environment. This applies to both individuals and organisations, including, of course, museums.

The measures described by Joanna Tabaka can be complemented with actions taken at the level of administrative procedures, e.g. by establishing the infrastructure of museum facilities which, by saving energy or using alternative sources of energy, can also contribute to the improvement of the situation aimed at halting global warming. Such measures are recommend- 
ed by the authors of the report „The Green Museum”, who believe that the museum operating as a "green museum” is a responsibility that stems from the mission of the institution, as a means of saving money and has an educational dimension by affecting both the employees and the environment to promote the adoption of environmental standards in their personal lives as well [Brophy, Wylie 2008: p.1-4]. This paper has been illustrated with examples from American museums, the practices of which are not always transferable overseas into Europe, including Poland. The reason for this is the distinct system of structuring, funding, and functioning of museum institutions in various geographical and cultural areas, involving very different traditions and histories of individual countries. There is however at least one area in which we can identify a common field, which is very extensively exploited and considered by many to be the most important contemporary activity of museums. The point is to engage in educational activities.

In May 2021, in connection with the pandemic situation in Poland, mini reconnaissance surveys were performed online, primarily regarding museum shops. A questionnaire with a number of open questions was distributed among students (future cultural managers from two Polish universities), culture users and museum professionals, inviting them to speak freely in the areas defined by the author of these words. Nearly one hundred people wished to express their opinions on the questions set out in the questionnaire. Certainly, this group should not be considered representative, and the responses gathered constitute only a very rough reconnaissance of the research grounds, which would require in-depth and exhaustive exploration.

The main focus of the survey was on museum shops. They have become a feature of almost every museum in recent years. Even if individual museums do not have a separate space that could be described as a museum shop, an increasingly wide range of products is available for purchase by visitors at the ticket counters.

Presumably, this was prompted in part by the fact that we have opened up to global museum trends, which have become very accessible with the expansion of mass tourism and the Internet. At the same time it should be stressed, as the respondents of the survey definitely do, that shops and sales in museums are becoming a way for the institutions to improve their finances. The latter aspect was particularly highlighted by the respondents, who see the shop as a vital element in the museum's everyday life and in- 
sist that shops are essential and „should exist...” ${ }^{1}$ because they make „...the average tourist enjoy the opportunity to bring a piece of traditional culture into their home, into their private space", souvenirs that are considered prestigious may be given to „loved ones” [Kotlers 426]. The financial means of support that a museum can secure through purchases in the shop is, as researchers of the problem have stressed, also an intentional desire on the part of visitors to support an institution that is considered valuable and worthy of sustaining [Kotlers, ibid.]. These shops also foster the natural need for consumerism that is so prevalent nowadays, while young peoplestudents of cultural management - emphasise the fact that people are no longer buying museum souvenirs as a result of their typically hefty price tag, but also because they follow the current trend towards minimalism in everyday life. Museum gift shops deserve more extensive research and in-depth analysis under interdisciplinary studies, but this moves beyond the focus of this essay, the contributory nature of which is merely an attempt to signal the problem and see the connections between climate and various areas of museum activity.

It may seem that the items that are sold in the shops are not an important aspect with regard to increasing the carbon footprint, reducing water levels or raising average temperatures. The aforementioned aspects of energy-efficient buildings, heating and lighting represent a much greater threat to the climate. It is incumbent on managers to make the right decisions in this respect, in an effort to contribute to saving our planet. However, museum merchandise is a kind of intermediary between the museum, the art (or history) presented there, museum professionals and guests, a link across generations, forging relationships and creating new qualities of life and existence in the world. A relevant inspiration when looking at the items marketed in museum shops with regard to the climate crisis was the recently published book by Christiana Figueres and Tom Rivett-Carnac: „The future we choose. The Stubborn Optimist's Guide to the Climate Crisis” [Figueres, Rivett-Carnac 2021]. Referred to as the „Architects of the Paris Agreement 2015”, the authors identify ten paths to follow in order to "create a future based on renewal” by constructing a world in which the release of greenhouse gases into the atmosphere is minimised, and the achievement of this goal requires „dozens of micro-solutions” [Figueres,

${ }^{1}$ All quotes have been taken from the conducted surveys. Contributions are at the author's disposal and remain anonymous. 
Rivett-Carnac 2021:110]. The above mentioned studies by Joanna Tabaka and her commitment expressed both in various media [e.g. https://www. facebook.com/joanna.tabakal and during conference speeches as well as private conversations were also inspiring.

These ,micro-solutions' identified by Figueres and Rivett-Carnac have been categorised into ten actions, of which they propose selecting one or two, as a prelude to ,doing what is necessary' [Figueres, Rivett-Carnac 2021:114]. Museums are one of the places where such steps can be taken, and applying similar a mindset to the goodies found in shops is indeed a ,micro' solution. The suggested approaches presented in this essay for following the authors' train of thought and seeking to adapt their postulates to museums can (perhaps) inspire thinking on how to save the world and make it a better place to live in. The intention here is not to pinpoint specific solutions, to pursue irrefutable truths and responses to ecological problems, but only to highlight certain possibilities for approaching the problem, constructing a kind of museum environment in which the search for answers to questions rarely asked on a daily basis is an appropriate and culturally fertile challenge. This phrase is meant to encompass a deep appreciation of the relationships that can be negotiated in the area called „nature-culture” and the fact that, although the boundaries between nature and culture are becoming less and less clear and blurred, they are still present in human consciousness and offer the possibility of creating regulations that affect the course of events.

Responses to a direct question in the surveys about the relationship between goodies and climate change also suggest that this line of thinking should be followed. The majority of respondents from all three groups do not recognise such a correspondence and expressed this in their answers (most often) with the phrase „NONE” or a visual representation: „...”. Viewing museum goodies in terms of their correlation with the climate was represented most prominently in the questionnaires sent by students. It was them that pointed out the consequences of selling souvenirs as "wasting resources", "producing and accumulating rubbish", especially adding to the carbon footprint when the items are "transported from China", and one can also find laconic statements that "buying unnecessary items does not save the planet”, "producing anything harms", and selling souvenirs from the Tate Modern exhibition "...Shapes of Decay: A Discussion about Art and Ecology, the narrative of which is centred around ways of under- 
standing environmentalism, addressing climate change etc.” is called "a kind of hypocrisy”. Awareness of the problem among young people may be regarded as a good sign, although it is clear from press reports, and perhaps above all from the aforementioned IPCC Report, that the world does not have time to wait for them to become decisive if humanity and its place to live are to be saved.

First two measures suggested by the Authors of the book in question [Figueres, Rivett-Carnac 2021: 115 - 124] relate to the way humans need to manage their relationship to time, to the past and to the future, and to create reality that makes it possible for the future to move in a desired direction offering potential for the life to flourish. An assertion about the need to „pay homage to the past” is probably applicable as an almost universal formula for defining a museum. Needless to document, the thinking of museums as a cultural area focused on paying homage to the past can be considered present and explicit both in the literature on the subject and in other, colloquial and common areas of cultural expression. Figueres and Rivett-Carnac, however, point to the further course of action that needs to be taken, which requires „letting go of the past” and „becoming immune to nostalgia” [p. 115]. Is it possible to think of museums as liberating from the past? Is it possible to imagine an institution that, although relying on resources from the past, is primarily oriented towards thinking about the world it is helping to create, about the future? Can one fathom that the heritage we store in museums is first and foremost intended to convey meaningful messages to pass them on to future generations? Would this also apply to the articles in the museum shops?

The survey revealed that goodies in the shops are most often bought as souvenirs to document a visit to a prestigious museum, ,a desire to boast about having visited a place”, „snobbery about a place”, while the most direct statement is that "the main purpose of that is to present oneself as a purely cultured person, belonging to a high society in some respect". A respondent points out that people trying to make purchases to fuel their own snobbery and prestige are most likely to reach for canvas bags printed with a painting — or other „visible” gimmicks — that ,just scream: look how cultured and avant-garde we are! An entire paper could be written on the behaviour of these groups, therefore I will only briefly state that they buy these goodies to create a certain image, rather than out of genuine interest in the subject”. This is yet further proof of the imperative that museum 
professionals sometimes seem to overlook, namely the importance of the awareness of current trends, cultural fashions, knowledge of the (not only) socio-cultural environment. What at a given moment is a symbol of prestige and fuels the human need for snobbery and being en vogue.

The items purchased in the shops are material manifestations of memory and carriers of values that are important to the customers, so important in fact that these artefacts perform educational functions, „to some extent complementing the Museum's mission of cultural learning, promoting all the concepts and ideas that are important to us”. Cultural Marketing specialist supports these insights by stating that currently „museums are unable to exploit marketing to what it is today: as a vehicle for analysis and a modus operandi to achieve the set objectives" [Tobelem 1998: 339 after: Chhabra 2010: 85].

One of the respondents to the circulated series of questions also highlighted the desire to have ,a small item that will remind me of the place”, a sentiment that quite clearly anticipates the time to come and the belief that it is in the future that one will want to return to the memories along with their relevance; ,a possible souvenir purchased at the shop would prompt me to visit venues of this kind in the future".

Was anything specified, then, about what this object of remembrance should be? Is it possible, in a museum shop, to make a commercial offer that meets economic, educational and cultural goals while at the same time reaching towards the future and opening up to the second action suggested by Figueres and Rivett-Carnaca [p.120], which is to have „... a clear vision of the future". The authors identify specific thinking/functioning paths to follow. Among the most noteworthy we can definitely list: „starting by questioning” and building on strong foundations - „imagination is the foundation” and the postulate of being attentive „to what is coming” [p. 124]. Museums are institutions that build their potential based on science, thus postulating social, cultural and marketing research is indispensable, which means focusing on the circumstances of their surroundings in order to create an appropriate offer.

Consumerism, mentioned above, is one of the trends omnipresent in the global contemporary world, and many respondents mentioned this very phenomenon as a reason for shopping in museum shops. A certain number of people argue that although items in museums ",are more sophisticated than, for example, in the Sukiennice (Kraków Cloth Hall), so they shape tastes better...” 
and being their owner has a more profound meaning (aesthetic, sentimental, etc.), „,buying is the realisation of the need to own things”, and „many people just buy things at fairs with junk, only for the sake of buying something". It is very explicitly expressed by Pope Francis in the pro-environmental encyclical „Laudato si”, which has an axiological significance in thinking about environmental impacts of climate change and actions to prevent them: "This paradigm leads people to believe that they are free as long as they have the supposed freedom to consume" warning that "obsession with a consumerist lifestyle, above all when few people are capable of maintaining it, can only lead to violence and mutual destruction" and he calls for "ecological conversion" [Francis 2015:176-177]. Francis proceeds purely from a position of religious faith, while Figueres and Rivett-Carnac, thinking in the spirit of citizenship, point to another action to give climate change its intended direction - to see “yourself as a citizen, not a consumer” [Figueres, Rivett-Carnac 2021:133] and try to argument by saying that „rather than meeting our needs, buying things in order to achieve a sense of satisfaction or belonging can become addictive and lead to self-doubt and confusion about our very identity and life direction" [Figueres, Rivett-Carnac 2021:136]. This statement is an exact contradiction of the missions pursued by museums and realised by striving to achieve the objectives set in the founding and strategic documents. Developing and strengthening local, regional or national identity, following values, creating an environment for the exchange of ideas and negotiating the meanings of contemporary culture are all mentioned and referred to in different ways as aspects in which museums should function with respect to contemporary challenges. There is a need, as the authors of the aforementioned book demonstrate, to redefine the concept of the "good life” and to free oneself from its consumerist model. The museum shop emerges as a necessity, which in some sense, mentioned above, contradicts the mission of the museum. But after all, one cannot „resent” the needs of the surroundings and stand with one's back to them, trying at the same time to impose own vision of the world and own ways of bringing it into being. Moreover, museum professionals stress the importance of financial benefits of selling merchandise in the shops by way of solutions that can be applied in museum shops. They postulate the following: "Become a better consumer" and "Dematerialize" [Figueres, Rivett-Carnac 2021:137 et seq.].

These include, firstly, to focus on the quality rather than the quantity of the product and seek assistance from companies that are "public about their val- 
ues, have made commitments to sustainability, and are part of organizations that certify" [p.137] After all, museums are quite experienced in this area, and the quality of museum merchandise is regarded as the main criterion for purchasing museum souvenirs, respondents admitted that „all souvenirs are distinguished by careful and aesthetic workmanship and artistic merit”. Except for aesthetic values, they are also unique in their originality, this criterion is being considered as an exceptional circumstance, such as: „I wouldn’t normally expect to see similar items in a shop in Poland”. The utilitarian aspect of the souvenirs was also important to many, although some were critical of selling items that are „...used every day and which we already owned, and which are covered with reproductions or museum logos in these kinds of museums” and are things that are „one-size-fits-all in every museum. For instance, the exact same pencil only with a different sticker". The quality of museum souvenirs is very often the reason for their high price, which in turn was mentioned by the respondents to the questionnaire as a reason not to make purchases.

It is important to note here that the criteria for making or refraining from purchases are most often dictated by very individual preferences, with no explicit awareness of civic responsibility on climate issues, sustainable development or the fair trade movement. A representative statement of one respondent that „I never kept track of where the postcard or pen I bought in the museum shop came from," was followed by the confession that „I guess they are not produced locally and always in a humane way”. The optimistic thing was that even when compiling the results from the conducted exploratory research, one had an impression that simply asking the question about the relationship between the fair trade movement and museums became a thought-opener and posed a question about a sense of responsibility. Respondents commented in a manner that represents the belief that „museum shops should not be abolished, but their standards and range of products ought to be revised".

Following in the footsteps of museum professionals, students and visitors from diverse backgrounds, we can suggest solutions that, however, will not completely eliminate climate risks, but in terms of avoiding unsustainable development or unfair trade can become micro-solutions offering, in the long run, a meso or even macro solution.

In fact, the respondents note that souvenirs sold in shops should preferably be „made of natural raw materials: clay, wood, straw, wicker, pine root, as 
well as fabric, thread, paper and metal”, they should be „made of environmentally friendly materials” and ,ideally of recycled origin”. A number of respondents addressed, albeit indirectly, the need to prevent the items sold in the museum shops from increasing the waste pool, viewing recycling and practicality as ways of dealing with the problem of excess waste, which has become one of the causes of the current environmental crisis. In his 2004 work: "Wasted Lives: Modernity and Its Outcasts" [Bauman 2004], Zygmunt Bauman centres his sociological interest primarily on the concerns of people and society. However, he begins by recounting Italo Calvino's literary vision from Invisible Cities, in which the author offers a vivid image of one of the cities, Leonia, as a place the residents of which use „new and different things" every day, while the old ones surround the city like a chain of mountains, which, with the wind at the right direction, poison the air of the central space and the „the all-fresh, all-glittering, all-fragrant innards of novelty shops” [Bauman 2004:2]. Outlining an image of the world through the lens of scraps and rubbish, Zygmunt Bauman anticipated a reality that might not have been so pronounced at the time but which today, several years after the sociologist's death, has become a terrifying reality for all of us and which the voices of those who would like museum goodies not to swell the pool of rubbish seem to be warning us about. It is important, however, to note a certain element articulated in the confession of one of the museums' employees: „I have been browsing in second-hand shops for years and very seldom come across museum goodies. Could it be that they are not necessarily thrown out?”. The writer of these words, in turn, has seen many „museum goodies” at various fairs and antique markets. Perhaps the very fact that they come from a museum and bear museum inscriptions renders them ennobled and endows them with the „patina of old age" so eagerly acquired, not only by museum professionals? The response of one academic also taking part in the survey corroborates this idea: ,...I don’t like to collect things, except... The ones which are unique: old, rare”, whereas their opinion on goodies in museums is that „... they should be more distinctive and unique (as unique as the museum is)".

This may be ensured by the practice mentioned quite often by respondents, arguing that museum shops should sell an assortment of products from local artists and creators. In the meantime, endorsing local producers can be „an opportunity to support (them)”, „local handicrafts deserve to be promoted", after all it is all for the benefit of the region's or locality's 
culture. While one student of cultural management, who admittedly described herself as someone who does not buy souvenirs, predominantly due to exorbitant prices, declares: „if, in addition, they are designed and produced exclusively for a specific institution or as regional products, then I am very much in favour”, supporting her argument more extensively: „I think that locally produced souvenirs offer a number of merits, both for the institution and the artist. They are individual in character, evoke certain emotions and promote local culture.

Handmade in the spirit of environmentalism, involving the local community in the life of the institution, perfectly fits with the concept of corporate social responsibility (CSR). Furthermore, the products offered in the shops can diversify the museum's merchandise and entice visitors to select a particular venue". The focus on raising entrepreneurship and the impact on the economy of a given region was evident in the comments of museum visitors who were not professionally involved with museums. After all, beyond the economic support of the museum itself, small, local businesses or individual manufacturers need to be supported as well, and the results of this support translate into „supporting Polish enterprises”. Concurrently — which, after all, is also postulated by Figueres and Rivett-Carnaca - it is about observing standards, i.e. thinking in a more global perspective about the operation of the fair trade movement. An expert on the problem, Katarzyna Wasilik, points out that „deconsumption (limited consumption), ecoconsumption, consumer ethnocentrism (preference for national, local products) are becoming an alternative for contemporary consumers”, [Wasilik 2015:102], while the titular responsible consumption means „consciously making shopping decisions based on information on where and how a given commodity was produced and selecting products the production of which did not involve human rights violations, environmental degradation or animal suffering” [Wasilik 2015:103]. More and more (especially young) people start to follow this train of thought: "if I saw a fair trade label on a museum souvenir, it would certainly convince me (even) more to buy it. It seems that the museum shop is not a large market - yet it's hard not to think about it when we consider global fair trade and the amount of Chinese stuff found in some shops. I believe that awareness-raising in this respect should also resonates in areas such as museum gift-shops." Responsible consumption may mean the Fair Trade practice of "granting of community development bonuses" aimed at „improving the living conditions and development of particular regions” [Wasilik 2015:106]. 
Following this idea may also mean acting to save the climate by implementing another postulate articulated by Figueres and Rivett-Carnaca defined as „Dematerialization” [Figueres, Rivett-Carnaca 2021: 137 et seq.]. This means exploiting technology with which we can "do without material objects while still enjoying the services that they provide" [ibid]. The striking thing is that the above is almost a model description of the specificity that museums offer us! For what else is interacting with works of art, or show-pieces on archaeological, historical or ethnographic exhibitions? Krzysztof Pomian drew attention to the exclusion of museum items from business, economic or utilitarian cycle [Pomian 2001: pp.19 et seq.], i.e. resignation from their use in social circulation, while at the same time building a domain of experience and knowledge in the process of visiting museum exhibitions. The fact that museums are sites of experience does not need to be addressed, yet one might point out that respondents also referred precisely to experience when commenting on museum shops: „People admiring the objects, the place they visit, and enjoying the experience are willing to take with them this piece of emotion and memory of a good time they spent together (...) and hence the desire to have a fragment of this reality”; „People want to have souvenirs of nice and pleasant places where they have been and where they have experienced something"; „After all, the most important thing is our memories and spiritual/intellectual museum experience (...) I don't go to an institution to purchase more things, I go to satisfy my higher needs”. After all, the above-mentioned „higher-order needs” do not necessarily need „material expression”, it is not a sine qua non condition for experiencing and retaining experiences, memories and the abundance of values and spiritual and intellectual resources encountered at the museum. The dematerialisation of the museum experience is therefore another way in which the museum's mission, focused on communicating higher goals, is or can be accomplished. There are different ways of achieving this. In addition to the technology, mentioned by Figueres and Rivett-Carnaca through which memories can be retained, one could point out, for example, the hosting of workshops presenting, for example, the techniques or ways of producing exhibits in the museum, building relationships, but also „it would be nice if museums held workshops where you could make/paint an exhibition-related souvenir yourself”, as one respondent quite aptly points out. The material and its use cannot and will not disappear completely, and the point is to change 
the style of consumption, at least until the world and its climate return to a sustainable equilibrium. Shops constitute a kind of buffer between worlds, one of which has been described by Zygmunt Bauman as comparable to a cemetery and "set away from the hurly-burly of daily life, separated from the business of life in their own enclosed space" where one does not eat, drink, run, or touch and limits the freedom of children [Bauman:128]. The shops separate this space from the "stage (which - KB) is meant to last or be conserved...frailty and transience are the names of the game" (ibid). Bauman also states that "values are values in as far as they are fit for instantaneous, on the-spot consumption. Values are attributes of momentary experiences. And so is beauty" [Bauman, 2004:122]. The argument for moving away from the production of trash follows, ergo: contributing to the deterioration of climate and creating a scenario in which museums will simply cease to exist. Visionary accounts in literature and fiction do not envisage this type of institution in a post-apocalyptic world. Lech M. Nijakowski, in the book describing the society in the post-apocalyptic world based on popular culture texts, stresses that ,the apocalypse is also the annihilation of things. In the old world, they provided us with comfort and security (...) while things and food unapologetically defamed in the old world by environmentalists suddenly become a way to redemption..." [Nijakowski 2018: 261], as „the functionality of many devices is no longer comprehensible. The remains of the old world are used in a new way" [ibid., p. 231] and there is no possibility or scope for excluding them from utilitarian circulation (Pomian), placing them in a cemetery (Bauman), or treating them as „dust collectors” (respondent in the survey).

Museum shops are usually the last link of the museum chain of experiences, yet still remain an integral part thereof. As one respondent wishes, and one has to agree, they should represent and be treated as ,an inherent part of the museum narrative”. The first link in the Holocene reality was the cloakroom, a place to put on the much ridiculed and hated felt slippers, keeping the floors from getting dirty and damaged (particularly relevant when visiting spaces, the original floors of which have been retained - e.g. the Palace in Kozłówka). The slippers have become a retrograde symbol for museums, replaced to their relief by plastic, disposable shoe protectors. Nowadays, perhaps for reasons that have been outlined in the merely informative dimension above, the idea of a return to a form of reusable and possibly recyclable protectors should be considered to help 
protect floors, which in some cases remains a necessity. Perhaps the protectors should be jointly produced with the visitors during the workshops? All museum activities, undertaken by staff and visitors alike, would then be bound together by thinking along the lines of saving the world from climate change. Whatever happens inside the boundaries produced in this way calls for more extensive studies, more in-depth research, drawing on the experience of specialists and the goodwill and hope that we are able to contribute to the final victory of life over death. Ultimately, museums which were created as a message from the Past to the Future were also designed with this intention and hope in mind. It is with this hope we remain, too. Not only for the sake of saving the world, but also for the fact that we are initiating a discussion, and publishing texts in ZWAM, which are devoted to this issue, hoping for a response from our dear readers.

\section{Bibliography}

Barańska Katarzyna, Muzeum w sieci znaczeń. Zarządzanie z perspektywy nauk humanistycznych, Wydawnictwo Attyka, Kraków 2013

Bauman Zygmunt, Wasted Lives. Modernity and its Outcasts, Polity Press, Cambridge 2004 Brophy S. Sarah, Wylie Elisabeth, The Green Museum. A Primer on Environmental Practice, AltaMira Press 2008

Chhabra Deepak, Sustainable Marketing of Cultural and Heritage Tourism, Routledge Critical Studies in Tourism, Business and Management, 2010

Figueres Christiana, Tom Rivett-Carnac, The Future We Choose. The Stubborn Optimist's Guide to the Climate Crisis. Alfred A. Knopf, New York 2020

ENCYCLICAL LETTER LAUDATO SI' OF THE HOLY FATHER FRANCIS ON CARE FOR OUR COMMON HOME https://www.vatican.va/content/francesco/en/encyclicals/documents/papa-francesco_20150524_enciclica-laudato-si.html (read: 30.11.2021)

Nijakowski Lech M., Świat po apokalipsie. Społeczeństwo w świetle postapokaliptycznych tekstów kultury popularnej, Wydawnictwo Naukowe Scholar, Warszawa 2018

Pomian Krzysztof, Zbieracze i osobliwości, Paryż - Wenecja, XVI - XVIII wiek, przeł. Andrzej Pieńkoś, Wydawnictwo UMCS, Lublin 2001

Sutton Sarah, The evolving responsibility of museum work in the time of climate change, Museum Management and Curatorship, 2020, VOL. 35, NO. 6 pp. $618-635$

Tobelem, J. (1998). The Marketing Approach in Museums. Museum, Management and

Curatorship, 16(4): 337-354, after: Chhabra Deepak, Sustainable Marketing of Cultural and Heritage Tourism, Routledge Critical Studies in Tourism, Business and Management, 2010

Wasilik Katarzyna, Idea Fair Trade. W kierunku odpowiedzialnej konsumpcji, Problemy Zarządzania, Finansów i Marketingu, Zeszyty Naukowe Uniwersytetu Szczecińskiego, issue 38:2015 (865), DOI: 10.18276/pzfm.2015.38-10, pp. $101-109$

Żabicki Piotr, Ewolucja i antropocen. Pytania o człowieka, https://nauka.uj.edu.pl/aktualnos ci/-/journal_content/56_INSTANCE_Sz8leL0jYQen/74541952/135130073, read: 10/08/2021) 


\section{Websites}

https://www.joannatabaka.pl/publikacje, access: 17/08/2021.

https://www.wilanow-palac.pl/co_mozna_zobaczyc_w_parku.html, read: 17/08/2021.

https://www.teraz-srodowisko.pl/aktualnosci/raport-IPCC-2021-zmiany-klimatu-10704.

html, access:16.08.2021

https://icom.museum/en/resources/standards-guidelines/museum-definition, read:

1.09.2021

\section{Katarzyna Barańska}

\section{„0 powrót muzealnych kapci” - czyli wskazanie wybranych możliwości reagowania przez muzea na trendy zmian w środowisku naturalnym i otoczeniu kulturowym}

Opublikowany w sierpniu 2021 Raport IPCC dotyczący przyszłości zmian klimatycznych nie pozostawiają wątpliwości, że wszyscy muszą podjąć starania o odwrócenie śmiertelnych trendów. Instytucje muzealne również są współodpowiedzialne za przyszłość planety, od tego zależy także i ich racja bytu. W tekście poruszony został zaledwie wycinek działań muzealnych, które są lub mogą być podejmowane w celu uczestnictwa w ratowaniu Ziemi. Dotyczą one ostatniego i wydawałoby się najmniej ważnego z ogniw działań muzealnych sklepików i pamiątek tam oferowanych. Wskazane zostały sposoby myślenia i organizowania sprzedaży pamiątek oraz argumenty na rzecz przeciwdziałania nadmiernemu konsumpcjonizmowi, potraktowane to zostało jako realizacja misji i istoty muzealnictwa.

Słowa klucze: zmiana klimatu, sklep muzealny, konsumpcja, zmiany kulturowe

\section{„For the return of museum slippers”, i.e. an indication of selected possibilities for museums to respond to trends in changes in the natural and cultural environment}

The IPCC Report on the Future of Climate Change, published in August 2021, leaves no doubt that everyone must work to reverse deadly trends. Museum institutions also share responsibility for the future of the planet, and their raison d'être also depends on it. Only a fragment of museum activities that are or may be undertaken in order to participate in saving the Earth is mentioned in the text. They concern the last and seemingly the least important link in museum activities - the shops and souvenirs offered there. The ways of thinking and organizing the sale of souvenirs were indicated, as well as arguments to counteract excessive consumerism, which was treated as the implementation of the mission and essence of museology.

Keywords: Climate change, museum shop, consumption, cultural changes 